\title{
HPV vaginal self-sampling among women non-adherent to Papanicolaou screening in Chile
}

\author{
Javiera Léniz, M en Epid, ${ }^{(1)}$ María Isabel Barriga, Gin,, ${ }^{(2)}$ Marcela Lagos, MC, Biól Mol, ${ }^{(3)}$ Carolina Ibáñez, MC,(4) \\ Klaus Puschel, $M$ en SP, (I) Catterina Ferreccio, $M$ en SP. ${ }^{(4)}$
}

Léniz J, Barriga MI, Lagos M, Ibáñez C, Puschel K, Ferreccio C. HPV vaginal self-sampling among women non-adherent to Papanicolaou screening in Chile. Salud Publica Mex 2013; 55: 162-169.

\begin{abstract}
Objective. To evaluate acceptance, preference and compliance with referral of vaginal self-sampling for the detection of Human papillomavirus (HPV) among women non-adherent to Papanicolaou (Pap) screening in Santiago, Chile. Materials and methods. Using multistage sampling we identified women aged 30-64 years who reported not receiving a Pap test in the previous three years and offered them Pap testing at the health center or vaginal self-sampling for HPV testing at home. Self-collected samples were analyzed with hybrid capture. All HPV+ women were referred for colposcopy, biopsy and treatment when needed. Results. I 254 eligible women were contacted; $86.5 \%$ performed self-sampling and $8.1 \%$ refused; 124 women were HPV+ (II.4\%: $95 \% \mathrm{Cl}$ 9.6-13.5) of whom $85.5 \%$ attended colposcopy; 12 had CIN2+ (I.I\%: $95 \% \mathrm{Cl}$ 0.5-I.7). Conclusion. HPV vaginal self-sampling can be easily implemented in Chile and could improve coverage, successfully reaching women who drop out of the screening program.
\end{abstract}

Key words: Human Papillomavirus; cervical screening program; non-responders; self-sampling; cervical cancer; Chile
Léniz J, Barriga MI, Lagos M, Ibáñez C, Puschel K, Ferreccio C. Autotoma vaginal para detección de virus del papiloma humano en mujeres no adherentes a tamizaje con Papanicolaou en Chile. Salud Publica Mex 2013; 55: I62-169.

\section{Resumen}

Objetivo. Evaluar la aceptación, preferencia y adherencia a seguimiento de la autotoma vaginal para detección del virus del papiloma humano (VPH) en mujeres inasistentes a Papanicolaou (Pap) en Santiago, Chile. Material y métodos. Mediante un muestreo polietápico se identificaron mujeres entre 30 y 64 años inasistentes a Pap por $<3$ años, invitándolas a realizarse un Pap en su centro de salud o una autotoma vaginal a domicilio. Las muestras fueron analizadas con captura de híbridos. Las mujeres VPH+ fueron referidas a colposcopía, biopsia y tratamiento en caso necesario. Resultados. I 254 mujeres elegibles fueron contactadas; $86.5 \%$ aceptó la autotoma vaginal y $8.1 \%$ la rechazó; 124 mujeres resultaron $\mathrm{VPH}+$ (I I.4\%: IC95\% 9.6-13.5) de las que $85.5 \%$ asistió a colposcopía; 12 tenían CIN2+ (I.I\%: IC95\% 0.5-I.7). Conclusión. La autotoma vaginal para detección de VPH es implementable en Chile y su utilización podría mejorar la cobertura del programa rescatando a mujeres inasistentes.

Palabras clave: Papilomavirus humano; autotoma vaginal; no adherentes; cáncer cervicouterino; programa de tamizaje; Chile

(I) Departamento de Medicina Familiar, Pontificia Universidad Católica de Chile. Santiago, Chile.

(2) Departamento de Ginecología y Obstetricia, Pontificia Universidad Católica de Chile. Santiago, Chile.

(3) Departamento de Laboratorios Clínicos, Pontificia Universidad Católica de Chile. Santiago, Chile.

(4) Departamento de Salud Pública, Pontificia Universidad Católica de Chile. Santiago, Chile.

Received on: November 22, 201I • Accepted on: December 6, 2012 
$\mathrm{I}_{\mathrm{c}}^{\mathrm{n}}$ Latin America, cervical cancer is the second leading cause of cancer death, ${ }^{1}$ and new cases are expected to increase by more than $75 \%$ in the next 20 years due to demographic changes. ${ }^{2}$ Papanicolaou-based cervical cancer prevention programs have reduced its mortality in developed countries. ${ }^{3,4}$ In Chile, cervical cancer mortality declined slowly in the last decade, from crude rates per 100000 women of 9.2 in 1999 to 7.6 in $2009,{ }_{,}^{5}$ but remains higher than in developed countries. Moreover, the incidence of high-risk human papillomavirus (HPV) infection is increasing in Chilean women, which could lead to an increase in cervical cancer in this population. ${ }^{6}$ The Chilean program offers a Pap test every three years for women aged 25 to 64 years; coverage was $64 \%$ in 2009,7 which is below than that of developed countries like the Netherlands $(80 \%)$ and Finland $(90 \%))^{3}$

Among the reasons that have been identified for which women do not attend Pap screening in Chile, are problems associated with the procedure such as fear and previous negative experiences, and barriers associated with the health system such as difficulty to obtain appointments, appointment scheduling that is incompatible with working hours, and women perceiving the health center personnel as uncaring or rude. ${ }^{8,9}$

New screening strategies based on the detection of high-risk HPV infection have shown to be more effective than cytological screening in detecting high-grade lesions and reducing cervical cancer mortality, ${ }_{10}^{10}$ being also more cost-effective than Pap screening. ${ }^{11,12} \mathrm{HPV}$ testing can be performed in vaginal samples obtained by women themselves; self-collected samples have demonstrated high agreement ${ }^{13,14}$ but lower sensitivity ${ }^{15,16}$ than samples collected by a health professional for the detection of HPV. Self-sampling is highly accepted by women worldwide. ${ }^{17,18}$ The objective of this study, conducted between October 2009 and June 2010 in Santiago, Chile, was to evaluate the use of HPV vaginal selfsampling among women who do not comply with the Pap screening program in order to determine acceptance to take the exam, preference for vaginal self-sampling and compliance with referral of HPV positive women, and whether this strategy could help overcome most of the barriers described above, in particular regarding transportation to the health center, time constraints and fear of the pelvic examination. Study outcomes were acceptance of vaginal self-sampling (percentage of women invited to participate in the study who perform self-sampling), preference (percentage of women who performed self-sampling who declare to prefer this test in the future) and compliance with colposcopy referral (percentage of HPV-positive women who attend colposcopy).

\section{Materials and methods}

Population. The study population was the residents of the area covered by the public health system of the Alejandro del Río health center in the Puente Alto county. This is a middle-low socioeconomic level county with an estimated population of 735000 , which is comparable with the majority of Chilean women (women's mean schooling: 10.7 years vs 10.3 years, household poverty: $11.6 \%$ vs $12.7 \%$ ). ${ }^{19}$ In accordance with the national cervical cancer program, this health center offers only Pap testing for cervical cancer screening, with coverage of around 54\% in 2009; appointments are usually scheduled from 8 am to 5 pm Monday to Friday and are generally readily available. The average distance from the health center to each household in the covered area is seven city blocks. Multistage sampling was used to identify a representative sample of women 30 to 64 years of age, residents of the geographic area covered by the Alejandro del Río health center who reported not attending Pap screening in the previous three years. City blocks were randomly selected and all households in them were visited once; if an eligible woman was identified at that visit but sampling was postponed, she was revisited up to two times. If there were more than one eligible woman at home, only one was selected using a Kish card. Hysterectomized and pregnant women were excluded.

Field personnel. Home visits were carried out by two community health monitors ("monitoras de salud") who were previously trained in the study protocol. Health monitors are women who reside in the catchment area of each health center, most of them have completed high school, and whose main task is to assist the health center personnel in their activities with the community, for which they receive a small per-activity payment or no payment at all. In this study, monitors were paid US\$ 2 per enrolled woman.

Field procedure. The health monitors were accepted inside the homes, usually in the living room, where they provided information -verbal and an illustrated brochure-about cervical cancer, HPV transmission and cervical cancer prevention. They then invited eligible women to attend the health center for a Pap test or to perform HPV vaginal self-sampling at the time of the visit. Women who refused self-sampling were asked to state the reason for refusal. Women who preferred self-sampling gave written informed consent and answered a survey regarding their socio-educational characteristics, reproductive history, Pap test history and smoking and sexual habits. Women were instructed 
to go to the bathroom, insert the brush (HC2 Collection Device) into the vagina, rotate it left and then right, and place it in the HC2 transport tube. The health monitor received the sample, placed it in an open glass container to avoid leaking, stored it in a cooler with a cold pack and transported it to the health center where it was stored in a refrigerator. After self-sampling, women were asked about satisfaction with the procedure and future test preference; one of the investigators (JL) recontacted by phone a $4 \%$ random sample of the participants to validate this information. Following laboratory recommendations, self-sampling was postponed if women were menstruating or using vaginal ovules.

Laboratory analysis. The HPV test used was Hybrid Capture 2 (HC2) High-Risk HPV DNA test, which is based on the detection of viral DNA by nucleic acid hybridization and is considered a standard test for HPV DNA screening. ${ }^{13}$ The technique identifies the presence of 13 oncogenic HPV genotypes. Samples were considered positive when the relative light unit/ cutoff (RLU/ $\mathrm{CO})$ was 1.0, as recommended by the manufacturer; diagnostic accuracy at higher viral load cutoff points was analyzed. ${ }^{20}$

The samples were labeled only with a unique study number and kept under refrigeration in the health center. Once a week were transported to the laboratory by research staff. Laboratory staff analyzed the samples according to the manufacturer's recommendations blindly.

Follow-up. Women who tested positive were contacted by one of the investigators (JL) in person (2 of 142) or by telephone (140 of 142). They were told that the test result was positive, explained the implications of an HPV-positive result which does not necessarily imply lesions or disease, but needed follow-up colposcopy; were told that colposcopy was a gynecologic exam with an instrument that allows a better visual examination of the cervix, to verify that the virus did not cause any lesions. They were referred to the Dr. Sotero del Río Hospital, where a trained gynecologist performed a colposcopy and biopsies when any suspicious lesion was observed. Biopsies were analyzed at the Pathological Anatomy Laboratory of the hospital, following the national cervical cancer program guidelines. Test results of HPV-negative women were sent via certified mail to their homes.

Statistical analysis. We estimated a sample size of 1000 women to detect a $90 \%$ of compliance with colposcopy referral, based on a 14\% HPV positive prevalence rate $(\mathrm{n}=140) .{ }^{21}$ Preference (yes/no) identified women`s re- sponses to the question 'would you prefer self-sampling in the future' which was obtained at the end of the visit. Compliance (yes/no) with referral to colposcopy refers to the HPV positive women who attended/not attended the follow-up appointment. Pearson's chi-square or ANOVA tests, depending on the variable, were used to assess differences in selected characteristics among women according to HPV test positivity, compliance with referral colposcopy and preference for future testing with self-sampling or Pap; statistical significance was set at $p<0.05$. Data analysis was performed using SPSS 15.0 for Windows.

This study was approved by the ethics committee of the Pontificia Universidad Católica de Chile School of Medicine and the ethics committee of the Southeast Metropolitan Health Service in August 2009.

\section{Results}

A total of 5900 household visits were performed, identifying 1345 women aged 30-64 years who reported not receiving a Pap test in the previous three years; 13 of them were excluded because there were more than one woman in the household; therefore 1332 women were selected (figure 1). Of these women, 66 were excluded due to hysterectomy and 12 due to pregnancy. Among eligible women, 102 (8.1\%) decided not to perform selfsampling and did not provide information to compare them with the accepting women; reasons for refusal were lack of interest $(38.2 \%)$, preference to attend health center $(26.5 \%)$, fear of the procedure (19.6\%) and lack of time (15.7\%). Additionally, 5.3\% postponed selfsampling and were not at home on the two call-back visits. Therefore, self-sampling was performed by 1085 women ( $86.5 \%$ of eligible); 1005 during the first visit and 80 at the second or third visit. There were 1076 samples available for testing, since 11 were lost due to leaking of the tube content; this problem was identified at the beginning of the study and was then corrected by instructing participants to place the tube in a glass jar immediately after sampling.

Table I presents the participants' opinions about self-sampling. After completing the self-collection procedure, $93.4 \%$ considered it to be slightly or not at all uncomfortable and $74.1 \%$ indicated they would prefer self-sampling at home if they had to repeat the test. When comparing women who would prefer selfsampling in the future with women who would prefer to attend the health center or were indifferent (preference), the two groups were similar in age (mean \pm SD: $46.2 \pm 8.9$ years vs $46.9 \pm 9.3$ years) and lifetime number of sexual partners, but women who preferred self-sampling had significantly higher education levels and more time 
Table I

HPV VAGINAL SELF-SAMPLING STUDY PARTICIPANTS' opinions Regarding Self-SAMPLING ( $\mathrm{N}=\mathrm{I}$ 085). ChILE, 2010

\begin{tabular}{|c|c|c|c|}
\hline Question & Answer & $N$ & $\%$ \\
\hline \multirow[t]{3}{*}{$\begin{array}{l}\text { How uncomfortable was } \\
\text { was self-sampling? }\end{array}$} & $\begin{array}{l}\text { Very uncomfortable or } \\
\text { uncomfortable }\end{array}$ & 57 & 5.3 \\
\hline & $\begin{array}{l}\text { Slightly uncomfortable or } \\
\text { not at all uncomfortable }\end{array}$ & 1013 & 93.4 \\
\hline & Indifferent & 15 & 1.3 \\
\hline \multirow{4}{*}{$\begin{array}{l}\text { Compared to Pap testing, } \\
\text { self-sampling was... }\end{array}$} & As uncomfortable & 46 & 4.2 \\
\hline & More uncomfortable & 15 & 1.4 \\
\hline & Less uncomfortable & 994 & 91.6 \\
\hline & Never had Pap test & 30 & 2.8 \\
\hline \multirow{3}{*}{$\begin{array}{l}\text { If you had to repeat the } \\
\text { test, would you prefer to... }\end{array}$} & Perform it yourself & 804 & 74.1 \\
\hline & $\begin{array}{l}\text { Have it done at the } \\
\text { health center }\end{array}$ & 84 & 7.7 \\
\hline & Indifferent & 197 & 18.2 \\
\hline
\end{tabular}

since last Pap test $(6.7 \pm 5.0 \mathrm{v} / \mathrm{s} 5.4 \pm 3.6, p<0.001)$ (table II). In the quality control interview of the 43 women who were re-contacted, the agreement between the answers obtained by the investigator and those obtained by the health monitor was 96\%; 100\% reported not feeling pressured by the monitor to participate.

In all, 124 (11.4\%: 95\% CI 9.6-13.5) women were positive for high-risk HPV (figure 1) and therefore were referred for colposcopy; 16 women refused to attend a follow-up appointment and two had relocated and could not be located; thus $85.5 \%$ complied with referral. Suspicious lesions were identified in 35 (33\%) colposcopies; 12 cervical intraepithelial neoplasia grade 2 or worse lesions (CIN2+) and seven cervical intraepithelial neoplasia grade 3 or worse lesions (CIN3+) were identified, including one cancer. The detection rate of precancerous lesions in the entire sample was 1.1\% (95\% CI 0.5\%-1.7\%) for CIN2+ and 0.7\% (95\% CI 0.2-1.1) for CIN3+.

Table II presents the characteristics of the participants according to HPV test positivity and compliance with colposcopy referral. Compared with HPV-negative women, HPV-positive women were significantly more likely to be single, to have more lifetime sexual partners and to not have a previous Pap test; additionally, they were more likely to be smokers and to have less schooling, but these differences did not reach statistical significance. HPV-positive women who attended colposcopy, compared with those who did not comply with follow-up, were more likely to have fewer children, to have a previous Pap test and to report less time since their last Pap test; however these differences did not reach statistical significance.

At the end of the study we gained access to the Ministry of Health cytology registry for the study area. This allowed us to verify the participants' report of the date of their last Pap test. Only 726 (66.9\%) women appeared in the registry; among them, 288 registered a Pap test within the previous three years and therefore did not meet the criteria of non-adherence to Pap screening; HPV positivity in these women was $9.8 \%$, while positivity in the "truly non-adherent" women was $11.8 \%$; compliance with colposcopy was similar among the two groups. Interestingly, all (12) CIN2+ lesions detected in our study were found in the subgroup of "truly nonadherent" women or women with no cytology registry $(p=0.02)$ (table III).

\section{Discussion}

Women who usually do not attend Pap screening have 2.5 times higher risk of cervical cancer ${ }^{22}$ and twice the risk of dying from this cancer ${ }^{23}$ than women who receive regular Pap screening. These women constitute, therefore, a higher risk population. This study shows that in Chile, vaginal self-sampling for high-risk HPV detection has high acceptability and can be an effective strategy to increase adherence to screening programs for cervical cancer; it can be easily incorporated as part of the national screening program to reach women noncompliant with the three-year interval Pap testing. The Chilean public health system devotes significant efforts each year to reach non-compliant women through outreach campaigns or home visits in order to motivate women to attend the health center for their routine Pap test. Considering that health care personnel perform routine home visits as part of various health programs, resources would be more efficiently invested if, during these home visits, non-compliant women were offered the self-sampling alternative.

If records of the women targeted by the cervical cancer program were available and their contact information was updated and credible, women who do not adhere to the program could be directly searched for and contacted by trained personnel. However, if the contact information is incomplete or inaccurate, as was in our study area, the efforts to search a particular woman can be excessive for local health centers. In this case it would be more efficient to search for non-adherent women via systematic household visits in the area to be covered; this strategy was chosen for our study, in which five household visits were required to identify one woman 
Table II

Characteristics of HPV vaginal self-sampling study participants according to HPV positivity AND COMPLIANCE With Referral to COLPOSCOPy. ChILe, 2010

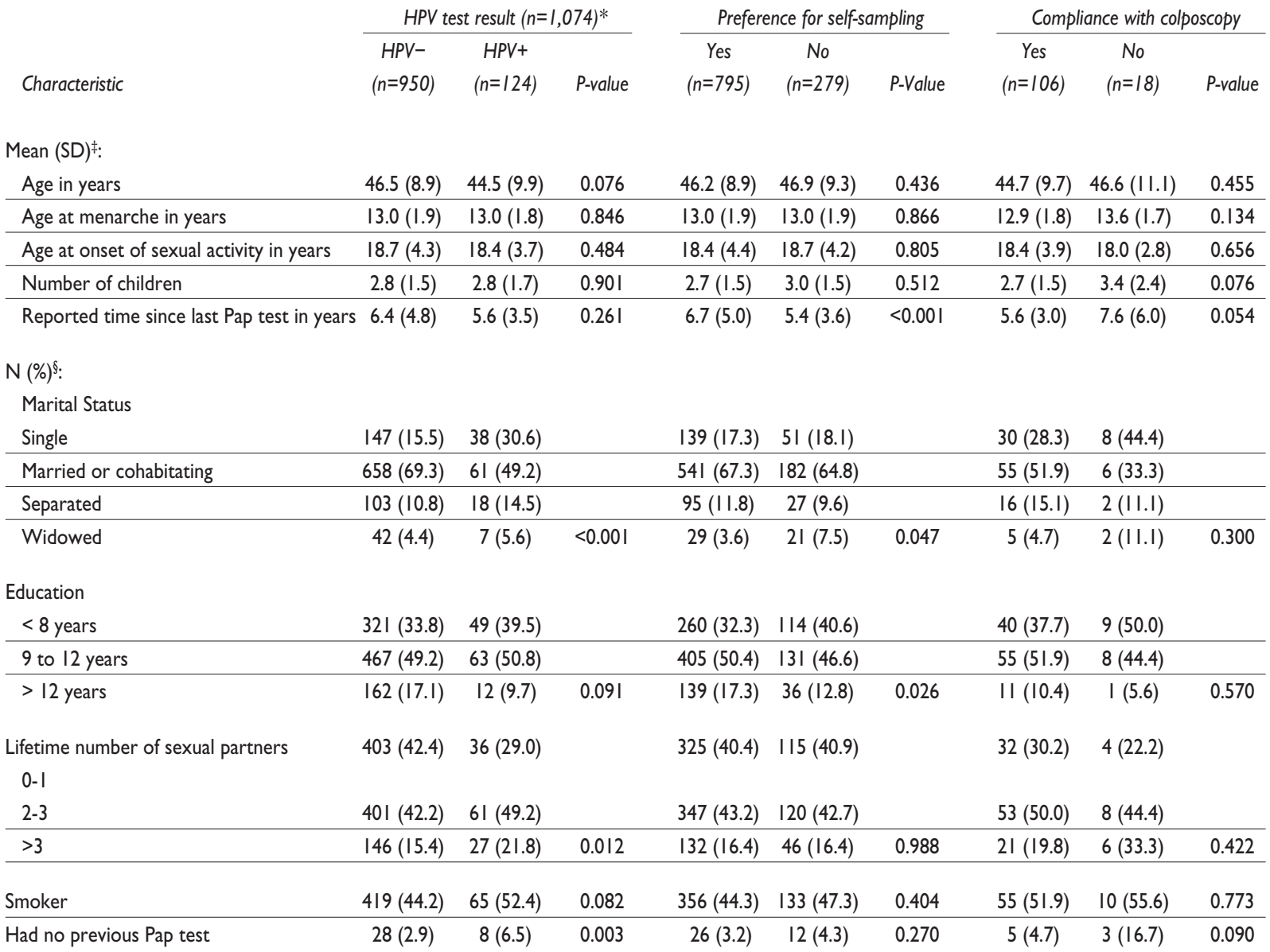

* I 085 women performed self-sampling; II samples were lost due to leakage of tube content.

$\ddagger$ ANOVA or ${ }^{\S}$ Chi-square test.

Bold: statistically significant at $p<0.05$.

who reported not having a Pap test in the previous three years. This strategy is highly reproducible in any Latin American country where a particular health center has a clearly assigned catchment area. Field workers require only a short training session and do not need to be professionals; additionally, since the HPV test does not require refrigeration of the samples for up to two weeks, they do not need to carry the excessive weight of a refrigeration device and therefore can perform visits in remote areas, as well as in those without electricity.

Some studies have shown low (27-58\%) acceptance of self-collected vaginal tests among women who do not attend cytological cervical screening. ${ }^{17,24}$ In these studies, women received a self-sampling kit for HPV testing with instructions and they were asked to return the self-collection tube to the laboratory. Our higher acceptance rate could be explained by the use of home visits, during which most women $(80 \%)$ provided the sample immediately, and by communicating positive test results in person or over the phone. An Italian study showed that acceptability of self-sampling was slightly lower in rural areas than in urban areas. ${ }^{25}$ Since our study was conducted in an urban area of Santiago, the reported acceptability may not be representative of rural areas of Chile; however most (86\%) Chilean women reside in urban areas. Since the socioeconomic status of our study population in terms of poverty and mean years of education are comparable to the national average, we believe the acceptability observed in our study is representative of what can be expected if this strategy were implemented nationwide. Although women with more schooling reported a higher preference 


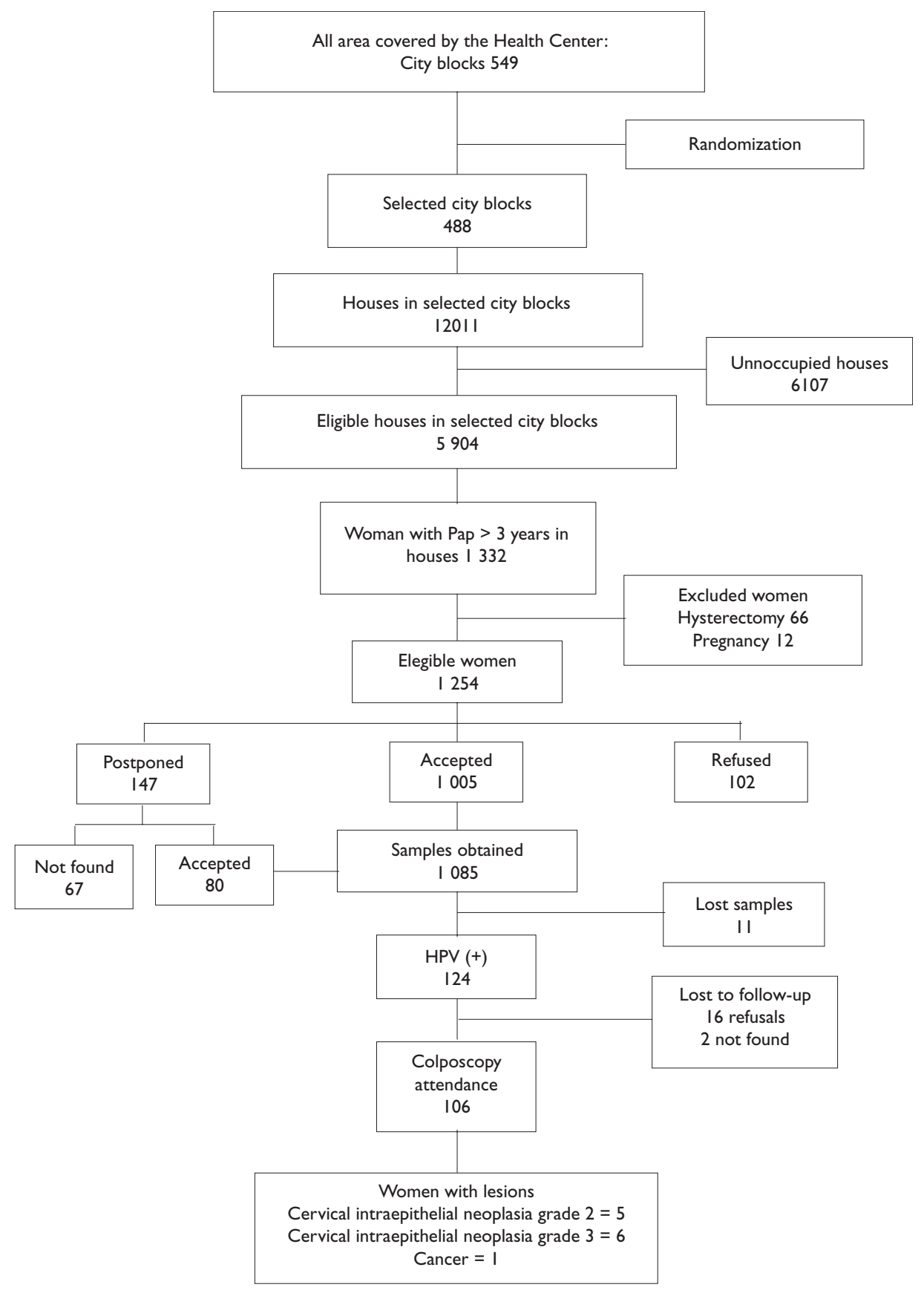

Figure I. Enrollment and outcomes of participants in the HPV vaginal self-sampling study. Chile, 20 I0.

for self-sampling over Pap testing than women with less schooling, both groups showed a 10 -fold preference for self-sampling; thus this strategy is applicable in women of all educational levels.

Some factors that can be associated with preference for vaginal self-sampling by non-attendees to Pap scree- ning might include experiencing less fear or discomfort during self-sampling and avoiding the feeling of embarrassment during a gynecological exam; ${ }^{18}$ in Chile, more than $30 \%$ of women who do not attend Pap screening identify these factors as the cause. ${ }^{8}$ In our study, over $90 \%$ of women who performed self-sampling reported 
Table III

OUTCOME OF HPV VAGINAL SELF-SAMPLING STUDY PARTICIPANTS ACCORDING TO TIME SINCE THEIR LAST PAP test registered in the Ministry of Health database. Chile, 2010

\begin{tabular}{|c|c|c|c|c|c|}
\hline $\begin{array}{l}\text { Time since last } \\
\text { Pap test in } \\
\text { registry (years) }\end{array}$ & $\begin{array}{l}\text { Women } \\
\text { (N) }\end{array}$ & $\begin{array}{l}\text { Mean age } \\
\text { (years } \pm S D \text { ) }\end{array}$ & $\begin{array}{c}\text { HPV } \\
\text { positivity } \\
(\%)\end{array}$ & $\begin{array}{c}\text { Colposcopy } \\
\text { compliance } \\
(\%)\end{array}$ & $\begin{array}{c}\text { CIN 2+ } \\
\text { lesions } \\
(\%)\end{array}$ \\
\hline$<3$ & 285 & $46.0 \pm 9.2$ & 9.8 & 89.3 & 0.0 \\
\hline $3-5$ & 313 & $46.4 \pm 9.0$ & 10.9 & 85.3 & 1.6 \\
\hline$>5$ & 120 & $47.0 \pm 8.9$ & 14.2 & 94.1 & 1.7 \\
\hline Not in registry & 356 & $46.3 \pm 8.9$ & 12.6 & 80.0 & 1.4 \\
\hline Total & 1074 & $46.3 \pm 9.0$ & 11.5 & 85.5 & I.I \\
\hline
\end{tabular}

less discomfort than with Pap testing. The acceptability of self-sampling is also related to its practicality and could be especially useful for women with difficulties accessing the health center; self-sampling is time saving -it took less than 10 minutes for a woman to provide the sample- and can be performed at home, without the need to travel, worry about child care, etc.

Adequate screening coverage alone does not guarantee success; good follow-up is essential. In Peru, only 25\% of women with an abnormal Pap test received appropriate follow-up. ${ }^{26}$ Moreover, women who do not undergo follow-up are at greater risk for high-grade lesions or cancer, ${ }^{26,27}$ and therefore should be a top priority group in any program. In Chile, follow-up of women who attend regular Pap screening is not a major problem according to the $90 \%$ rate reported by the national health program.${ }^{28}$ However, almost half of the women with invasive cervical cancer do not attend screenings, as evidenced in a study conducted in the same area as ours that reported that $48 \%$ of women with cancer had not received Pap screening in the previous three years. ${ }^{29}$ It is in these non-adherent women that compliance with follow-up could become a problem if they were "rescued" into the screening program by self-sampling. In our study, not only did we observe a good response to self-sampling, but also a high compliance with followup $(80 \%)$, similar to rates reported elsewhere. ${ }^{17,30}$ Our study included 285 participants who reported not receiving a Pap test in the previous three years, but who in fact had a more recent Pap test, as later discovered during the revision of the Ministry of Health registry; compliance with colposcopy was similar in all women, regardless of their real screening adherence status.

In our study, over $60 \%$ of HPV positive women had a negative colposcopy and, among those who underwent biopsy, $34 \%$ were negative. A triage test is required to refer women to colposcopy; various options are now under discussion, such as Pap testing, HPV genotyping and molecular markers of a more advanced stage of infection. ${ }^{31}$

Today there is enough evidence to argue that the reformulation of cervical cancer screening programs should be based on detection of HPV, given its greater sensitivity, greater objectivity and better cost-effectiveness compared with cytological screening, even in developing countries. ${ }^{11,12}$ One of the limitations reported in some studies of HPV self-sampling is a lower sensitivity for the detection of high-grade precancerous lesions when compared to clinician-collected specimens. ${ }^{32}$ However, the high acceptability of this technique could overweigh the disadvantage in sensitivity, especially with the increase in coverage of screening programs. Moreover, a recent study showed that the sensitivity of self-sampling can be improved using a different collection technique. ${ }^{33}$

This study shows that vaginal self-sampling is an adequate strategy to improve the effectiveness of the cervical cancer program by increasing screening in a high-risk group and is associated with a high response to further diagnostic and treatment procedures. The questions that remain are the feasibility of implementation and the best approach for scaling it to the entire country. Home visiting may increase the cost of implementing a strategy to increase coverage in non-attendees to Pap screening based on self-sampling. Future studies could assess the implementation of other recruiting strategies and their effects on response to screening.

\section{Acknowledgements}

We would like to acknowledge the significant contributions of: field coordinators Paz Cook and Paz Santana; colposcopists Jorge Brañes, Jaime Cartagena and Felipe Nuñez; molecular biologist Helena Poggi; the pathology team lead by Martha Pruyas; epidemiologist Solana Terrazas; statistician Francisca Gonzalez; the coordinator of the women's program Daysi Viñales; and the scientific edition of Vanessa Van De Wyngard.

The authors declare having received a donation of self-sampling kits of Hybrid Capture-2 test from QIAGEN (Gaithersburg, MD, USA). QIAGEN was not involved in the study design, field work or in the analysis of the study. This study was financed by the Fondo Nacional de Desarrollo Científico y Tecnológico (FONDECYT grant $\mathrm{N}^{\circ}$ 1090597), from the Ministerio de Salud de Chile.

Declaration of conflict of interest: Te authors declare that they have no conflict of interests. 


\section{References}

I. World Health Organization. (WHO) 2008. The globocan project [Accessed October 20, 20I I] Available at: http://globocan.iarc.fr 2. Parkin DM, Almonte M, Bruni L, Clifford G, Curado MP, Pineros M. Burden and trends of type-specific human papillomavirus infections and related diseases in the Latin America and Caribbean region. Vaccine 2008;26 SI I:LI-LI5.

3. van der Aa MA, Pukkala E, Coebergh JW, Anttila A, Siesling S. Mass screening programmes and trends in cervical cancer in Finland and the Netherlands. Int J Cancer 2008; I 22: 1854- 8558.

4. Peto J, Gilham C, Fletcher O, Matthews FE. The cervical cancer epidemic that screening has prevented in the UK. Lancet 2004:364:249-256. 5. Departamento de Estadísticas e Información de Salud. (Ministerio de Salud de Chile). [Accessed September 17, 20I I] Available at: http://deis. minsal.cl)

6. Ferreccio C, Van De Wyngard V, Olcay F, Domínguez MA, Puschel K, Corvalán $\mathrm{AH}$, et al. High-risk HPV infection after five years in a population-based cohort of Chilean women. Infect Agent Cancer 201 I;6:2I. 7. Ministerio de Salud de Chile, Departamento de Estadísticas e Información de Salud. Cobertura (\%) PAP vigente en mujeres beneficiarias de 25 a 64 años, según Servicio de Salud. SNSS 2008-2009. [Accessed June 8, 2012] Available at: http://deis.minsal.cl/cobertura/PAP/CoberturaPAP_SNSS.htm

8. Urrutia MT, Poupin L, Concha X, Viñales D, Iglesias C, Reyes V. ¿Por qué las mujeres no se toman el Papanicolau?: Barreras percibidas por un grupo de mujeres ingresadas al programa de cáncer cervicouterino AUGE. Rev chil obstet ginecol 2008;73:98-103.

9. Urrutia MT. Creencias sobre Papanicolaou y cáncer cérvicouterino en un grupo de mujeres chilenas. Rev Chil Obstet Ginecol 2012;77:3-10. I0. Sankaranarayanan R, Nene BM, Shastri SS, Jayant K, Muwonge R, Budukh AM, et al. HPV screening for cervical cancer in rural india. N Engl J Med 2009;360: I385-1394.

II. Goldie SJ, Gaffikin L, Goldhaber-Fiebert JD, Gordillo-Tobar A, Levin C, Mahe $\mathrm{C}$, et al. Cost-effectiveness of cervical-cancer screening in five developing countries. N Engl J Med 2005;353:2I 58-2168.

12. Flores YN, Bishai DM, Lorincz A, Shah KV, Lazcano-Ponce E, Hernandez M, et al. HPV testing for cervical cancer screening appears more cost-effective than Papanicolau cytology in Mexico. Cancer Causes Control 20II;22:26I-272.

13. Petignat P, Faltin DL, Bruchim I, Tramer MR, Franco EL, Coutlee F. Are self-collected samples comparable to physician-collected cervical specimens for human papillomavirus DNA testing? A systematic review and meta-analysis. Gynecol Oncol 2007;105:530-535.

I4. Brink AATP, Meijer CJLM, Wiegerinck MAHM, Nieboer TE, Kruitwagen RFPM, van Kemenade F, et al. High concordance of results of testing for human papillomavirus in cervicovaginal samples collected by two methods, with comparison of a novel self-sampling device to a conventional endocervical brush. J Clin Microbiol 2006;44:25 I8-2523.

15. Salmeron J, Lazcano-Ponce E, Lorincz A, Hernandez M, Hernandez P, Leyva A, et al. Comparison of HPV-based assays with Papanicolaou smears for cervical cancer screening in Morelos state, Mexico. Cancer Causes Control 2003; I 4:505-5I2.

16. Szarewski A, Cadman L, Mallett S, Austin J, Londesborough P, Waller J, et al. Human papillomavirus testing by self-sampling: Assessment of accuracy in an unsupervised clinical setting. J Med Screen 2007;14:34-42. 17. Bais AG, van Kemenade FJ, Berkhof J, Verheijen RH, Snijders PJ, Voorhorst F, et al. Human papillomavirus testing on self-sampled cervi- covaginal brushes: An effective alternative to protect nonresponders in cervical screening programs. Int J Cancer 2007; 120:1505-1510.

I8. Dzuba IG, Diaz EY, Allen B, Leonard YF, Lazcano-Ponce EC, Shah KV, et al. The acceptability of self-collected samples for HPV testing vs. the Pap test as alternatives in cervical cancer screening. J Womens Health Gend Based Med 2002;1 1:265-275.

19. Ministerio de Desarrollo Social de Chile. Encuesta CASEN 2009. [Accessed June 8, 20I2] Available at: http://www.ministeriodesarrollosocial. gob.cl/casen/index.html\#

20. Meijer CJ, Berkhof J, Castle PE, Hessenlink AT, Franco EL, Ronco G, et al. Guidelines for human papillomavirus DNA test requirements for primary cervical cáncer screening in women of 30 years and older. Int J Cancer 2009;124:516-520.

21. Ferreccio C, Prado R, Luzoro A, Ampuero S, Snijders P, Meijer Ch, et al. Population-Based Prevalence and Age Distribution of Human Papillomavirus Among Women in Santiago, Chile. Cancer Epidemiol Biomarkers Prev 2004;I3(I2):227I-226.

22. Odongua N, Chae YM, Kim MR, Yun JE, Jee SH. Associations between smoking, screening, and death caused by cervical cancer in Korean women. Yonsei Med J 2007;48: 192-200.

23. Andrae B, Kemetli L, Sparen P, Silfverdal L, Strander B, Ryd W, et al. Screening-preventable cervical cancer risks: Evidence from a nationwide audit in Sweden. J Natl Cancer Inst 2008; 100:622-629.

24. Wikstrom I, Stenvall H, Wilander E. Attitudes to self-sampling of vaginal smear for human papilloma virus analysis among women not attending organized cytological screening. Acta Obstet Gynecol Scand 2007;86:720-725.

25. Giorgi Rossi P, Marsili LM, Camilloni L, lossa A, Lattanzi A, Sani C, et al. The effect of self-sampled HPV testing on participation to cervical cancer screening in Italy: A randomised controlled trial (ISRCTN9607/600). $\mathrm{Br} J$ Cancer 20I I; 104:248-254.

26. Gage JC, Ferreccio C, Gonzales M, Arroyo R, Huivin M, Robles SC. Follow-up care of women with an abnormal cytology in a low-resource setting. Cancer Detect Prev 2003;27:466-47I.

27. Kinlen LJ, Spriggs, Al. Women with positive cervical smears but without surgical intervention. Lancet 1978;312:463-465.

28. Suarez E, Prieto M, Rojas I, Fernandez B, Prado R, Olfos P. Programa nacional de cáncer cervicouterino. Rev Chil Obstet Ginecol 2001;66:480. 29. Arellano R. Sobrevivencia en cáncer cervicouterino. Servicio de Salud Metropolitano Sur Oriente. Tesis para optar al grado de Magíster en Salud Pública. Escuela de Salud Pública Facultad de Medicina Universidad de Chile. [Accessed May 22, 2012] Available at: http://campusesp.uchile. cl:8080/dspace/bitstream/I23456789//52/I/Ruth\%20Arellano_MSP20--. pdf

30. Gok M, Heideman DA, van Kemenade FJ, Berkhof J, Rozendaal L, Spruyt JW, et al. HPV testing on self collected cervicovaginal lavage specimens as screening method for women who do not attend cervical screening: cohort study. Brit Med J 2010;340:c1040.

31. Almonte M, Murillo R, Sanchez GI, Jeronimo J, Salmeron J, Ferreccio $C$, et al. New paradigms and challenges in cervical cancer prevention and control in Latin America. Salud Publica Mex 2010;52:544-559.

32. Schmeink CE, Bekkers RL, Massuger LF, Melchers WJ. The potential role of self-sampling for high-risk human papillomavirus detection in cervical cancer screening. Rev Med Virol 201 I;21:139-153.

33. Belinson JL, Du H, Yang B, Wu R, Belinson SE, Qu X, et al. Improved sensitivity of vaginal self-collection and high-risk human papillomavirus testing. Int J Cancer 20 I2; 130: I855-1860. 